\title{
Comparative Assessment of the Microbiological and Physicochemical Quality of a Laboratory Brewed 'Burukutu' and Commercialized Products Sold in Some Markets in Port Harcourt Nigeria
}

\author{
Francis Sopuruchukwu Ire, Precious Afoke Edio and Ndukwe Maduka
}

\section{ABSTRACT}

Burukutu is an indigenous, brown coloured, cloudy, alcoholic beverage traditionally brewed using mainly sorghum grains. This study was aimed at the comparison of microbial quality, physicochemical properties, proximate composition and minerals content of laboratory brewed burukutu (LBB) and commercial products sold in some markets in Port Harcourt. Sixteen (16) samples of the commercialized product were evaluated from Elele (EM), Rumuokoro (RM) and Choba (CM) markets, Port Harcourt, Rivers State using Standard Methods while LBB was produced in our laboratory using Standard Procedures. Our result indicated an increase in aerobic mesophiles, total coliforms, faecal coliforms, fungi and lactic acid bacteria (LAB) counts during the early stages of the brewing process of laboratory produced burukutu but only LAB was detected in the final product. The overall microbial count of burukutu from the three markets revealed that $\mathbf{C M}>\mathbf{E M}>\mathbf{R M}$ although all the samples had higher microbial count compared with the LBB. Staphylococcus aureus, Escherichia coli, Lactobacillus sp., Lactobacillus sp., Aspergillus sp. and Saccharomyces cerevisiae were present during the brewing stages of burukutu. Enterobacter aerogenes and Mucor sp. were detected in the commercial samples purchased from the three markets. Lactobacillus fermentum and $\boldsymbol{L}$. brevis had the highest and least frequency of occurrence in all the samples, respectively. The $\mathbf{p H}$, titratable acidity, alcohol content and soluble solids of the fermenting $\mathrm{LBB}$ were within the range of 3.0$3.4,0.6-0.97 \%, 3.0-4.7 \%$ and $0.98-0.99 \%$, whereas in the commercialized samples, the equivalent values were 3.0-3.1, 0.00-0.10\%, 2.1-4.0\% and 0.65$0.82 \%$, respectively. Moisture, crude fat, ash, crude protein and carbohydrate content of the commercialized samples were within the range of $29.1-31.2 \%$, $10.8-14.2 \%, 3.8-4.85 \%, 2.9-5.7 \%$, and $44.7-51.7 \%$ compared to the range of values obtained in the LBB $(52.1 \%, 15.7 \%, 9.8 \%, 7.6 \%$ and $15.4 \%)$, respectively. The following minerals elements $\mathrm{K}, \mathrm{Ca}, \mathrm{Na}, \mathrm{Zn}$ and $\mathrm{Mg}$ present in the LBB were higher than the values obtained in the commercialized alcoholic beverage. The results from this study, suggest that the quality of LBB is better than the commercialized products. Therefore, it is recommended that in order to improve the overall quality of commercially brewed burukutu for the benefit of everyone irrespective of social status, good manufacturing practices (GMP) and good hygienic practices (GHP) should be strictly adhered to by local producers and vendors.

Keywords: Sorghum, Brewing, Burukutu, Microbiological, Physicochemical, Food Quality and Safety.

\section{INTRODUCTION}

Burukutu, sometimes referred as BKT is a brown coloured alcoholic beverage brewed traditionally by Africans which has the flavour of vinegar [1]. The opaque colour of burukutu is due to the presence of yeast materials and suspended solid [2]-[3]. It is consumed by an estimated population of 10 million people in West Africa especially in
Published Online: October 8, 2020

ISSN: $2684-5199$

DOI : $10.24018 /$ ejbio.2020.1.5.85

F. S. Ire*

Department of Microbiology, Faculty of Science, University of Port Harcourt, Nigeria. (francis.ire@uniport.edu.ng)

P. A. Edio

Department of Microbiology Technology, Faculty of Science Laboratory Technology, University of Port Harcourt, Nigeria.

\section{N. Maduka}

Department of Biological Science, College of Natural and Applied Sciences, Wellspring University, Benin City, Edo State, Nigeria.

(maduka.ndukwe@wellspringuni.edu.ng)

*Corresponding author 
life, inconsistent organoleptic properties and unsatisfactory conservation, burukutu is far less attractive to lovers of alcoholic beverages compared with Western beers. High patronage of burukutu instead of Western beers especially among impoverished individuals and low income earners is because it is an affordable alcoholic beverage [1]. European barley beers generally have less nutritional value compared with sorghum beer as a result of high yeast content, Lactic acid bacteria and other suspended materials. Brewing of burukutu involves lactic acid fermentation unlike European beer [6]. Lactic acid which is always present in burukutu and $\mathrm{pH}$ of the product ranging between 3.3-3.5 is responsible for its sour taste [7]-[8].

Traditionally, the preparation of burukutu mainly involves the use of starchy grains of guinea corn (Sorghum bicolor and Sorghum vulgare), millet and maize which involves several stages [8]-[9]. Sorghum is a staple food for the poor, providing protein and energy for millions of people especially those living in the Southern Sahara [10]. Burukutu which is regarded as a cereal food drink is an income earner for women that produce it at household level [11]. It serves as a cheap meal for anyone any time of the day [4]. One litre (1 L) of burukutu contains 5.9 and $26.7 \mathrm{~g}$ of protein and starch, respectively. Burukutu contains varying levels of iron, ascorbic acid, sodium, vitamins, manganese, magnesium, calcium and phosphorus depending on the raw materials used for its preparation [2], [12].

The stages involved in preparing burukutu are steeping, germination, fermentation, and maturation. Oftentimes, further enhancement of aromatic properties of burukutu is achieved by adding garri during its production [13]. At the fermentation stage, mainly bacteria, yeast and sometimes mould is involved. Candida and Saccharomyces are the predominant yeast while Lactic acid bacteria such as Lactobacillus, and Leuconostoc are found in burukutu. Bacteria associated with sorghum seeds and the finished product (burukutu) are Lactobacillus cellobiosis, L. fermentum, L. bulgaris, Leuconostoc meseteroides, and acetic acid bacteria while the fungi involved are Saccharomyces chavelieria, Candida krusei and C. guilliermondii [14].

Burukutu is largely produced in households usually under unhygienic conditions. Also, the use of contaminated water and poor personal hygiene of the processors predisposes the product to microbial contamination [10]. Most often, burukutu is sold and consumed in a microbiologically active state within a highly populated vicinity where its production takes place [4]. Burukutu has a short shelf life ranging between 1-8 days which could be attributed to low titratable acidity, lactic acid and alcohol content, high concentration of vitamins as well as the presence of lipoxidation products [14]-[15]. However, spoilage of burukutu could be delayed for almost two weeks if the product is pasteurized [3]. Extending the shelf life of European beer is achieved by flash-pasteurization. Disappointingly, it promotes starch gelatinization in sorghum beer which increases its viscosity, cause the removal of amylolytic enzymes and active yeasts resulting in poor effervescence [6].

In recent times, many researchers have assessed the microbiological quality, mineral contents, physicochemical properties and proximate composition of burukutu sold in different towns and localities [3], [5], [14]-[15]. Currently, there is limited studies which compared the quality of burukutu sold in various locations and a similar product brewed in the laboratory using standard procedures. Consequently, this study is aimed at comparing the microbiological quality, proximate composition, minerals content and physicochemical properties of burukutu sold in different locations in Port Harcourt with a similar product brewed in a laboratory-controlled environment.

\section{MATERIALS AND METHODS}

\section{A. Sample collection}

A total of sixteen (16) samples of burukutu made from sorghum were randomly purchased from three locations Elele, Rumuokoro and Choba markets in Port Harcourt, Rivers State. From each of the markets, four (4) samples of burukutu were randomly purchased from four (4) vendors using sterile plastic bottles with a lid. All the samples were kept in ice pack and transported immediately to the Food and Industrial Microbiology Laboratory, University of Port Harcourt for analysis within $12 \mathrm{~h}$. Also taken to the laboratory alongside the samples of burukutu were five kilograms $(5 \mathrm{Kg})$ of sorghum grains (Sorghum bicolor) purchased from a trader in Alakahia market, Port Harcourt using sterile plastic buckets with a lid and ten kilograms (10 $\mathrm{Kg}$ ) of garri from another trader.

\section{B. Isolation of Saccharomyces cerevisiae from commercial burukutu}

\section{Serial dilution}

A composite sample of the commercialized burukutu were serially diluted by pipetting $1 \mathrm{ml}$ of the stock sample into $9 \mathrm{ml}$ of normal saline using a sterile automatic pipette. This process was repeated till $10^{-6}$ dilution was obtained using sterile pipette for each transfer.

\section{Isolation and identification of yeasts}

The $10^{-3}$ and $10^{-4}$ dilutions of the composite sample of commercialized burukutu was plated into Yeast extract dextrose agar plates in duplicates using pour plate method. The culture plates were incubated for $72 \mathrm{~h}$ at room temperature $\left(24-37{ }^{\circ} \mathrm{C}\right)$ after which the colonies observed were subcultured repeatedly unto fresh plates to obtain pure colonies. Macroscopic examination of the isolates was determined in accordance with the methods described by [16]-[18] while microscopical examination of the isolates involved using the procedure adopted by [19]. Lactophenol cotton blue staining of isolates involved placing a drop of lactophenol cotton blue stain on a clean slide, and with the aid of a mounting needle, a small portion of mycelial was placed on the slide. A cover slip was gently placed on the slide. The slide was observed under the light microscope with $\mathrm{x} 10$ and $\mathrm{x} 40$ objective lenses. The yeast (Saccharomyces cerevisiae) isolated from commercialized burukutu was used for fermentation of the sorghum wort during the process of preparing laboratory brewed burukutu. 


\section{Laboratory-controlled brewing of burukutu}

\section{Malting}

The procedure described by [7], [15] was adopted. Sorghum grains were manually sorted to remove any foreign materials, damaged and non-viable grains. Four kilogrammes $(4 \mathrm{Kg}$ ) of sorted sorghum grains (Sorghum bicolor) were steeped overnight using tap water inside a clean plastic container. The steeped grains were drained to remove water using a sieve placed on a plastic container, thereafter, the grains were spread on a clean flat surface for malting process at room temperature $\left(25-37{ }^{\circ} \mathrm{C}\right)$. The steeped grains were sprayed with tap water thrice a day for 3 days to aid proper grain wetting and germination.

\section{Drying}

The malted grains were dried in hot air oven for $10 \mathrm{~h}$ to halt germination.

\section{Milling}

The sundried malted sorghum grains were milled into flour.

\section{Mashing}

Three kilograms (3 Kg) of the malted sorghum was weighed and mixed with adjunct (garri) and warm water in the ratio of 1:2:6, respectively. The mixture was stirred and allowed to settle for $30 \mathrm{~min}$. Afterward, $2 \mathrm{~L}$ of a clear supernatant was decanted from the mixture, the remaining mash was boiled for $1 \mathrm{~h}$ and allowed to cool for $40 \mathrm{~min}$. The supernatant was added to the cooled mash and allowed to stand for $12 \mathrm{~h}$. The mixture was filtered using a sieve; the resulting wort was further boiled for $1 \mathrm{~h}$ and allowed to cool (40-60 min.) before it was pitched with a pure culture of Saccharomyces cerevisiae isolated from commercial burukutu to initiate fermentation process for a period of $12 \mathrm{~h}$.

\section{Preparation of starter culture of yeast for pitching}

A loopful of the yeast was taken and serial dilution of the culture was carried out. One millilitre $(1 \mathrm{ml})$ of the dilution of Saccharomyces cerevisiae was taken using a sterile automatic pipette and added to $10 \mathrm{ml}$ of the prepared sorghum wort followed by 3 teaspoons of glucose and left to activate for $6 \mathrm{~h}$.

\section{Fermentation of sorghum wort}

The method described by [7] with slight modification was adopted. The activated yeast was used to inoculate the sorghum wort. The setup was allowed to ferment for $48 \mathrm{~h}$ at room temperature inside an improvised $5 \mathrm{~L}$ fermentation bucket which has a plastic tap. Samples of the wort was collected before boiling, after boiling, before fermentation with the pure culture of yeast, first $24 \mathrm{~h}$ of fermentation and final day of fermentation. A sample of the final product (burukutu) was aseptically collected for further analyses.

\section{Microbiological analyses}

\section{Homogenization and serial dilution}

Ten grams (10 g) of burukutu was added to $90 \mathrm{ml}$ sterile Salt peptone solution (SPS) containing $0.1 \%$ peptone and $0.85 \% \mathrm{NaCl}$, with $\mathrm{pH}$ adjusted to 7.2 and homogenized for $30 \mathrm{~s}$. This was followed by a ten-fold serial dilution using the homogenate $(1: 10)$. Aliquots $(1 \mathrm{ml})$ of dilution $10^{-3}$ and $10^{-4}$ were directly inoculated into Petri dishes containing appropriate isolation media. All analyses were done in duplicate. This procedure was used for analyzing both the laboratory brewed and the commercialized burukutu from the three markets. Other samples analysed include the ground sorghum grain before mashing, after mashing, the supernatant of the mash, the boiled wort, the fermenting wort at intervals of $12 \mathrm{~h}$ for the 2 days' fermentation period.

2. Enumeration and confirmation of total coliforms

Total coliforms were enumerated by the pour plate method using MacConkey agar and incubated at $37{ }^{\circ} \mathrm{C}$ for $24 \mathrm{~h}$. Discrete colonies were subcultured after $24 \mathrm{~h}$ on Nutrient agar. Identification of the isolates were confirmed based on colony morphology, Gram staining and biochemical reactions using the [20] as a guide.

3. Enumeration of aerobic mesophiles

Aerobic mesophiles were enumerated by the pour plate method using Plate count agar. The culture plates were incubated at $30{ }^{\circ} \mathrm{C}$ for $24 \mathrm{~h}$. The colonies were subcultured on Nutrient agar for $24 \mathrm{~h}$ at $30{ }^{\circ} \mathrm{C}$. The isolates were subjected to Gram staining and biochemical tests.

4. Enumeration and confirmation of Escherichia coli

Escherichia coli were enumerated by the pour plate method using Eosin methylene blue agar and incubated at $44{ }^{\circ} \mathrm{C}$ for $24 \mathrm{~h}$. The colonies were confirmed based on morphological features and biochemical tests [21].

\section{Enumeration of yeasts and moulds}

Yeasts and moulds were enumerated by the pour plate method using Potato dextrose agar and incubated at $25{ }^{\circ} \mathrm{C}$ for 3 days. The colonies were enumerated and subcultured into freshly prepared PDA plates. The identification of the yeast isolates from burukutu was based on microscopic and macroscopic observations. Also, lactophenol cotton blue staining of the isolates were carried out.

\section{Enumeration and isolation of lactic acid bacteria}

Lactic acid bacteria were enumerated by pour plate method using de Man, Rogosa and Sharpe (MRS, Oxoid CM361) agar. The plates were incubated in an anaerobic jar at $30{ }^{\circ} \mathrm{C}$ for $24 \mathrm{~h}$. Aliquot portion of lactic acid bacteria colonies from the MRS culture plate was picked using a sterile wire loop and subcultured repeatedly on freshly prepared MRS plates until pure colonies were obtained [22].

\section{Gram reaction}

Gram reaction was performed on the bacterial isolates. A smear of each isolate was prepared on a grease-free slide, then flooded with the primary stain, crystal violet for $60 \mathrm{~s}$. Afterward, the slide was rinsed off under running water, then flooded with the mordant (Lugol's Iodine) for $60 \mathrm{~s}$. and rinsed. Thereafter, it was decolourized with ethanol, for 30 s., and rinsed. Then, the slides were flooded with the secondary stain, Safranin for $30 \mathrm{~s}$. For drying of the slides, they were kept in a slanting position. The slides were viewed under the oil immersion objective lens of the microscope.

\section{Catalase reaction}

A drop of $3 \%$ freshly prepared hydrogen peroxide was placed on a clean glass slide and aliquot portion of the pure culture was picked and emulsified using a sterilized wire loop. The appearance of bubbles or effervescence resulting from the liberation of free oxygen as gas bubbles indicate the presence of catalase in the culture. Lack of bubbles indicates a negative reaction. 


\section{Oxidase test}

Oxidase test of the isolates were carried out using Identification Sticks (Oxoid Ltd., Basingstoke, Hampshire, $\mathrm{UK})$.

\section{Microscopic examination}

Cell shape and arrangements were determined using the Phase contrast microscope and the wet mount technique. A drop of sterile distilled water was placed on a clean slide followed by aliquot pure culture, and emulsified. A coverslip was gently placed on top of the solution on the slide and examined under the microscope using the $\mathrm{x} 40$ magnification and oil immersion using the $\mathrm{x} 100$ objective lens.

\section{Growth at different temperatures}

Two tubes containing MRS broth (Oxoid CM359) were inoculated with pure colonies of the test organism and incubated at $15{ }^{\circ} \mathrm{C}$ and $45{ }^{\circ} \mathrm{C}$, respectively for $72-96 \mathrm{~h}$. Growth in the tubes were determined by visual turbidity after the incubation period. This procedure was repeated for all the isolates.

\section{Fermentation of glucose}

The ability of the isolates to ferment and produce gas from glucose was determined using MRS sugar basal medium. The medium was composed of peptone $10 \mathrm{~g}$, yeast extract $5 \mathrm{~g}, 80 \mathrm{1ml}$, dipotassium hydrogen phosphate $2 \mathrm{~g}$, sodium acetate $5 \mathrm{~g}$, tri-ammonium citrate $2 \mathrm{~g}, \mathrm{MgSO}_{4} .7 \mathrm{H}_{2} \mathrm{O}$ $0.2 \mathrm{~g}, \mathrm{MnSO}_{4} .4 \mathrm{H}_{2} \mathrm{O} 0.05 \mathrm{~g}, 1$ litre distilled water, $\mathrm{pH} 6.5$, thus without glucose and meat extract. The basal medium was dispensed in $5 \mathrm{ml}$ aliquot into test-tubes containing inverted Durham tubes and sterilized by autoclaving at $121{ }^{\circ} \mathrm{C}$ for $15 \mathrm{~min}$. The glucose was prepared as $10 \%$ solution and sterilized by filtration, then it was added aseptically to the basal medium to achieve a final concentration of $2 \%$. The inoculated tubes were examined for the production of gas after incubation at $30{ }^{\circ} \mathrm{C}$ for $72 \mathrm{~h}$.

\section{Salt tolerance test}

Salt tolerance test was done using MRS broth (Oxoid CM359) containing $6.5 \%$ and $18 \%(\mathrm{w} / \mathrm{v}) \mathrm{NaCl}$ with incubation period of 4 days at $30{ }^{\circ} \mathrm{C}$. The tubes were then observed for growth of the inoculums.

\section{Growth at different $p H$ (4.4 and 9.6)}

Growth of the isolates in MRS broth (Oxoid CM359) with $\mathrm{pH}$ adjusted to 4.4 and 9.6 using concentrated $\mathrm{HCl}$ and $0.1 \mathrm{M} \mathrm{NaOH}$, respectively was determined by visual turbidity after $72-96 \mathrm{~h}$ of incubation at $30^{\circ} \mathrm{C}$.

\section{Identification of lactic acid bacteria $(L A B)$}

The LAB isolates were identified based on their morphological and microscopic observations as well as biochemical reactions. The ability of the isolates to grow at different temperatures and $\mathrm{pH}$, ferment supplied sugars as described by [20] were also determined.

\section{E. Physicochemical analyses}

\section{Determination of $\mathrm{pH}$}

The solid samples and distilled water were weighed in a ratio of $1: 1$, homogenized in a stomacher bag and the $\mathrm{pH}$ determined with a pH meter (Radiometer PHM 92; Radiometer Analytical A/S, Bagsvaerd, Denmark) after calibration using standard buffers. The $\mathrm{pH}$ of liquid samples was determined directly.

\section{Determination of titratable acidity}

For each sample of burukutu, $10 \mathrm{ml}$ of sample was made up to $200 \mathrm{ml}$ with distilled water and $80 \mathrm{ml}$ titrated against $0.1 \mathrm{M} \mathrm{NaOH}$ using $1 \%$ freshly prepared phenolphthalein as indicator. One millilitre of $0.1 \mathrm{~N} \mathrm{NaOH}$ was taken as equivalent to $0.009 \mathrm{~g}$ lactic acid.

\section{Determination of alcohol content}

The percentage of alcohol content of the fermenting burukutu was determined using [23]. One hundred millilitre $(100 \mathrm{ml})$ of each sample was diluted with $50 \mathrm{ml}$ of distilled water. The mixture was then distilled with about $100 \mathrm{ml}$ of the distillate collected. The specific gravity of the distillate was determined by a ratio of the weight of $25 \mathrm{ml}$ of the distillate by the weight of equal volume of water using the $25 \mathrm{ml}$ specific gravity bottle at $20{ }^{\circ} \mathrm{C}$. The value obtained was then referred to [23] to determine the percentage alcohol.

\section{Determination of soluble solids}

Soluble solids were determined by placing a drop of the sample on the lens of a hand held refractometer and the reading taken through the eye piece as Brix.

\section{F. Proximate analysis of burukutu samples}

The moisture, ash, crude protein, and crude fat content of samples of the burukutu were determined using the standard method of [24]. The analyses were conducted in triplicate and all reagents were of analytical grade.

\section{Moisture}

Empty moisture dishes were weighed using an electronic balance. About $2 \mathrm{ml}$ of each sample were poured into the moisture dishes and also weighed. The sample was placed in a hot air oven at a temperature of $105^{\circ} \mathrm{C}$. After $90 \mathrm{~min}$., the dishes inside the oven were removed, allowed to cool inside a dessicator and then reweighed. The percentage of moisture content was calculated using the mathematical formulae below:

$$
\% \text { moisture }=\frac{\mathrm{c}-\mathrm{a}}{\mathrm{b}-\mathrm{a}} \times 100
$$

where:

$\mathrm{a}=$ empty moisture dish;

$\mathrm{b}=$ weight of dish + sample before evaporation;

$\mathrm{c}=$ weight of dish + sample after evaporation

2. Ash

A modified [24] method was used to determine the ash content of the samples. The weights of empty crucibles were measured using an electronic balance. Each sample was poured into it a crucible and the weight taken. The crucibles containing the samples were put in furnace at a temperature of $600{ }^{\circ} \mathrm{C}$. After $75 \mathrm{~min}$. the ashes of the samples in the crucibles were removed from the furnace, kept in the desiccator for 10-15 min. to cool and reweighed. Ash content of the sample was calculated using the formula below.

$$
\% \text { ash }=\frac{\mathrm{c}-\mathrm{a}}{\mathrm{b}-\mathrm{a}} \times 100
$$

where:

$\mathrm{a}=$ empty crucible 
$\mathrm{b}=$ weight of crucible + sample before combustion;

$\mathrm{c}=$ weight of crucible + sample after combustion .

\section{Crude fat}

Burukutu samples were poured into moisture dishes and placed in a hot air oven at $105{ }^{\circ} \mathrm{C}$ for $75 \mathrm{~min}$. for evaporation to occur. Empty thimble was weighed (a) and 5 $\mathrm{ml}$ of the dried samples were measured and weighed (b). A piece of cotton wool was used to cover the mouth of the thimble to prevent spillage, and then also weighed (c). The samples were put in the fat extraction chamber containing ethanol as a solvent, allowed to boil for $30 \mathrm{~min}$. to extract oil from the sample. Afterward, the thimbles were removed from the fat extractor and placed in a desiccator to dry, then weighed (d). The percentage of fat was calculated using the formula below.

$$
\text { Crude fat }(\%)=\frac{c-d}{b-a} \times 100
$$

where:

$\mathrm{a}=$ weight of empty thimble;

$\mathrm{b}=$ weight of Sample and thimble;

$\mathrm{c}=$ weight of sample, cotton wool, and thimble;

$\mathrm{d}=$ dried sample in the thimble with the cotton.

\section{Crude protein}

The method described by [23] was adopted. Ten millilitres $(10 \mathrm{ml})$ of the sample was added to $0.05 \mathrm{ml}$ of $0.5 \%$ phenolphthalein indicator. Then, it was mixed and allowed to stand for about 5 minutes and neutralized with $0.1 \mathrm{M} \mathrm{NaOH}$ to the standard pink colour. Two millilitres ( $2 \mathrm{ml}$ ) of formalin was then added, mixed and allowed to stand for about five minutes. The new achieved acidity was titrated with $0.1 \mathrm{M} \mathrm{NaOH}$ until the same pink colour was obtained. Then, $2 \mathrm{ml}$ of the formalin and $10 \mathrm{ml}$ of $\mathrm{H}_{2} \mathrm{O}$ were titrated separately with $0.1 \mathrm{M} \mathrm{NaOH}$ as blank.

\section{Carbohydrate}

The carbohydrate content of the samples was determined by the difference method by subtracting the crude protein, crude fat, moisture and ash contents from 100

Carbohydrate $=100-($ crude protein + crude fat + moisture

$$
+ \text { ash) }
$$

\section{G. Analysis of minerals in burukutu samples}

Five grams $(5 \mathrm{~g})$ of the sample was weighed into a conical flask containing $5 \mathrm{ml}$ of concentrated $\mathrm{H}_{2} \mathrm{SO}_{4}$ (tetraoxosulphate $\mathrm{VI}), 10 \mathrm{ml}$ of trioxonitrate $(\mathrm{V})$ acid and 10 $\mathrm{ml}$ of $\mathrm{HCl}$ (hydrochloric acid) and boiled on a hot plate until the solution was clear. The digest was allowed to cool, then filtered into a standard flask and made up to the mark with distilled water. Minerals such as potassium, calcium and sodium were determined using flame photometer. Other minerals such as iron, zinc, phosphorus and magnesium were determined using atomic absorption spectrophotometer (ASS-BUCK 210 VGP model).

\section{H. Statistical analysis}

Variance analysis (ANOVA) and Tukey (at 5\% probability) statistical tool was employed to analyse the data (triplicate) using the IBM SPPS package version 22
Computer program. Data were presented as the means \pm standard errors of the means (SEM) of at least three independent experiments except otherwise stated.

\section{RESULTS}

The mean microbial count of the laboratory brewed burukutu monitored at the early stages of the brewing process and the final product (burukutu) are presented in Table 1. The result obtained shows that mashed sorghum grains before boiling (BB) were $6.62 \log _{10} \mathrm{CFU} / \mathrm{ml}$ for aerobic mesophiles, $5.73 \log _{10} \mathrm{CFU} / \mathrm{g}$ for total coliforms, $5.23 \log _{10} \mathrm{CFU} / \mathrm{ml}$ for faecal coliform, $3.36 \log _{10} \mathrm{CFU} / \mathrm{ml}$ for fungi and $1.376 \log _{10} \mathrm{CFU} / \mathrm{ml}$ for Lactic acid bacteria (LAB). The supernatant (SU) and sediment (SE) samples recorded a further increase in the mean microbial numbers $(\mathrm{CFU} / \mathrm{ml})$ which were 8.88 and $9.7 \log _{10} \mathrm{CFU} / \mathrm{ml}$ for aerobic mesophiles; 7.50 and $7.8 \log _{10} \mathrm{CFU} / \mathrm{ml}$ for total coliform count; 7.52 and $7.52 \log _{10} \mathrm{CFU} / \mathrm{ml}$ for faecal count; 6.9 and $6.34 \log _{10} \mathrm{CFU} / \mathrm{ml}$ for total fungal count 9.11 and $8.34 \log _{10} \mathrm{CFU} / \mathrm{ml}$ for lactic acid bacteria, respectively. However, there was no culturable microorganism in the boiled (BB) wort. Similarly, aerobic mesophiles, total coliforms, faecal coliforms and fungi were not detected during the period of fermentation of burukutu. On the contrary, there was a slight increase in LAB count from 3.61-3.7 $\log _{10} \mathrm{CFU} / \mathrm{ml}$ in the laboratory brewed burukutu within $48 \mathrm{~h}$ fermentation period. All the microbiological parameters monitored during the early stages of the brewing process and period of fermentation of burukutu brewed in the laboratory were significantly different $(p<0.05)$ except faecal coliform count of the supernatant and sediment.

TABLE 1: MiCROBIAL COUNT (LOG 10 CFU/ML) OF LABORATORY-BREWED BURUKUTU MONITORED AT DIFFERENT STAGES OF PREPARATION AND

\begin{tabular}{cccccc}
\multicolumn{7}{c}{ FERMENTATION OF THE FINAL PRODUCT } \\
\hline Sample & AMC & TCC & FC & TFC & LAB \\
\hline BB & 6.62 & 5.73 & 5.23 & 3.36 & 1.37 \\
SU & 8.8 & 7.5 & 7.52 & 6.9 & 9.11 \\
SE & 9.7 & 7.8 & 7.52 & 6.34 & 8.34 \\
BW & 0 & 0 & 0 & 0 & 0 \\
F-24 h & 0 & 0 & 0 & 0 & 3.61 \\
F-48 h & 0 & 0 & 0 & 0 & 3.7 \\
\hline
\end{tabular}

Key: AMC- Aerobic mesophiles; TCC- Total coliform count; FCFaecal coliform; TFC-Total fungal count; LAB-Lactic acid bacteria. BB Sorghum mash before boiling, SU-Supernatant before boiling; SESediment before boiling; BW- boiled wort, F-fermentation time.

The mean microbial count of burukutu sampled from Elele, Rumuokoro and Choba markets and laboratory brewed burukutu are presented in Fig. 1. The total bacterial count (TBC), total fungal count (TFC), total coliform count (TCC), faecal count (FC) and lactic acid bacteria count (LCC) of commercialized burukutu obtained from Rumuokoro markets were 6.99, 6.92, 7.96, 7.08 and 7.11 $\log _{10} \mathrm{CFU} / \mathrm{ml}$, respectively. As for the samples obtained from Elele market, the TBC, TFC, TCC, FC and LBCC were $7.01,7.96,7.0,7.08$ and $7.14 \log _{10} \mathrm{CFU} / \mathrm{ml}$, respectively. The TBC, TFC, TCC, FC and $\mathrm{LBCC}$ of burukutu samples from Choba market were 7.95, 7.9, 7.94, 7.04 and $7.13 \log _{10} \mathrm{CFU} / \mathrm{ml}$, respectively. The LAB count in the laboratory brewed burukutu was $3.66 \log _{10} \mathrm{CFU} / \mathrm{ml}$. 
The morphological characteristics of the isolates from the laboratory brewed burukutu at various preparation stages are presented in Table 2. The bacterial and fungal isolates were identified as Lactococcus sp., Lactobacillus sp., Escherichia coli, Saccharomyces cerevisiae, and Aspergillus sp. The result of biochemical tests of the bacterial isolates from the commercialized burukutu obtained from the three markets are presented in Table 3. The isolates were identified as Escherichia coli, Staphylococcus aureus, and Enterobacter aereogenes.

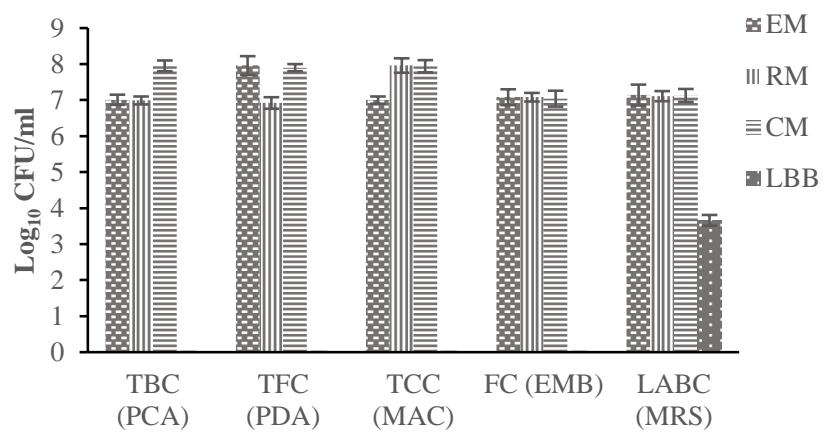

Microbial growth

Fig. 1. Mean microbial counts in burukutu sampled from Elele, Rumuokoro and Choba markets and Laboratory brewed burukutu (final product).

Key: TBC-Total bacterial count; TFC-Total fungal count; TCC-Total coliform count; FC-Faecal count, LABC-Lactic acid bacterial count; PDAPotato dextrose agar; MaC-MacConkey agar; PCA-Plate count agar; EMBEosin methylene blue Agar; PDA-Potato dextrose agar, MRS-de Man Rogosa and Sharpe Agar; EM-Elele market; RM- Rumuokoro market, CMChoba market, LBB-Laboratory brewed burukutu.
TABLE 2: MORPHOLOGICAL CHARACTERISTICS OF MICROORGANISMS Found In Burukutu SAMPLES AT EARLy STAGES DURING THE BREWING

\begin{tabular}{|c|c|c|c|c|c|}
\hline \multicolumn{6}{|c|}{ PROCESS } \\
\hline Plate & Colour & Shape & Size & Elevation & Probable organism \\
\hline PDA & Brown & round & $4 \mathrm{~mm}$ & Flat & $\begin{array}{c}\text { Saccharomyces } \\
\text { cerevisiae }\end{array}$ \\
\hline PDA & Black & round & $3 \mathrm{~mm}$ & Slightly raised & Aspergillus sp. \\
\hline $\mathrm{MaC}$ & Pink & round & $2 \mathrm{~mm}$ & Raised & Escherichia coli \\
\hline EMB & $\begin{array}{l}\text { Metallic } \\
\text { sheen }\end{array}$ & round & $2 \mathrm{~mm}$ & Slightly raised & Escherichia coli \\
\hline MRS & Creamy & rod & $2 \mathrm{~mm}$ & Slightly raised & Lactobacillus sp. \\
\hline MRS & Creamy & cocci & $2 \mathrm{~mm}$ & Slightly raised & Lactococcus sp. \\
\hline
\end{tabular}

The biochemical profile of ten (10) lactic acid bacterial isolates from the laboratory brewed burukutu is presented in Table 4. Two of the isolates were Lactococcus lactis whereas the remaining isolates were Lactobacillus plantarum, $L$. acidophilus and $L$. fermentum. The biochemical profile of thirteen (13) Lactic acid bacterial isolates found in the commercialized burukutu from Elele market is presented in Table 5. Two of the isolates were Lactococcus lactis whereas the remaining eleven isolates were identified as Lactobacillus brevis, L. plantarum, $L$. acidophilus, and L. fermentum. Depicted in Table 6 is the biochemical profile of fourteen (14) isolates grouped as Lactic acid bacteria found in commercialized burukutu obtained from Choba market. Two of the isolates were Lactococcus lactis while twelve of the isolates were Lactobacillus brevis, L. plantarum, L. acidophilus, and $L$. fermentum. The biochemical profile of LAB found in commercialized burukutu obtained from Rumuokoro market is presented in Table 7. A total of twelve LAB isolates were found in the samples of which three of the isolates were $L$. lactis whereas the remaining isolates were Lactobacillus plantarum, L. acidophilus, and L. fermentum.

TABLE 3: BIOCHEMICAL CHARACTERIZATION OF BACTERIAL ISOLATES FOUND IN BURUKUTU From THE THREE MARKETS

\begin{tabular}{ccccccccccc}
\hline $\begin{array}{c}\text { Isolate } \\
\text { code }\end{array}$ & $\begin{array}{c}\text { Grams } \\
\text { stain }\end{array}$ & Shape & Catalase & Coagulase & Motility & Indole & MR & VP & Citrate & Probable organism \\
\hline $\mathrm{X}$ & -ve & rod & + & - & + & + & + & + & - & Escherichia coli \\
$\mathrm{Y}$ & $+\mathrm{ve}$ & rod & + & + & - & - & - & + & - & Staphylococcus aureus \\
$\mathrm{Z}$ & -ve & rod & - & - & + & - & - & + & + & Enterobacter aerogenes \\
\hline
\end{tabular}

Key: MR-Methyl Red test, VP -Voges Proskauer test.

TABLE 4: Biochemical Profile Of LACTIC ACID BaCteria Found In THE LABORATORy BREWEd BuRUKUTU

\begin{tabular}{|c|c|c|c|c|c|c|c|c|c|c|}
\hline Test\Isolate & 1 & 2 & 3 & 4 & 5 & 6 & 7 & 8 & 9 & 10 \\
\hline Shape & rods & rods & rods & rods & rods & rods & rods & cocci & cocci & rods \\
\hline Gram stain & + & + & + & + & + & + & + & + & + & + \\
\hline Catalase & - & - & - & - & - & - & - & - & - & - \\
\hline Oxidase & - & - & - & - & - & - & - & - & - & - \\
\hline Anaerobic growth & + & + & + & + & + & + & + & + & + & + \\
\hline $\mathrm{CO}_{2}$ from glucose & - & - & - & - & + & + & + & - & - & + \\
\hline Growth at $\mathrm{pH} 4.4$ & + & + & + & + & + & + & + & - & - & + \\
\hline Growth at pH 9.6 & + & + & + & + & + & + & + & + & + & + \\
\hline Growth in $6.5 \% \mathrm{NaCl}$ & - & + & + & + & + & + & + & + & + & + \\
\hline Growth in $18 \% \mathrm{NaCl}$ & - & - & - & - & - & - & - & + & + & - \\
\hline Growth at $15^{\circ} \mathrm{C}$ & + & - & - & - & - & - & - & - & - & - \\
\hline Growth at $45^{\circ} \mathrm{C}$ & - & + & & + & + & + & + & - & - & + \\
\hline Galactose & + & + & + & + & + & + & + & + & + & + \\
\hline Lactose & + & + & + & + & + & + & + & + & + & + \\
\hline Arabinose & + & - & + & - & + & + & + & + & + & + \\
\hline Mannitol & + & - & - & - & + & + & + & - & - & + \\
\hline Maltose & + & - & - & - & + & + & + & + & + & + \\
\hline Mannose & - & - & - & - & + & + & + & - & - & + \\
\hline Fructose & + & + & - & + & + & + & + & + & + & + \\
\hline Raffinose & + & - & + & - & - & - & - & - & - & - \\
\hline Probable LAB & A & $\mathrm{B}$ & $\mathrm{B}$ & $\mathrm{B}$ & $\mathrm{C}$ & $\mathrm{C}$ & $\mathrm{C}$ & $\mathrm{D}$ & $\mathrm{D}$ & $\mathrm{D}$ \\
\hline
\end{tabular}

Key: A - Lactobacillus plantarum; B - Lactobacillus acidophilus; C - Lactobacillus fermentum; D - Lactococcus lactis; LAB - Lactic acid bacteria. 
European Journal of Biology and Biotechnology www.ejbio.org

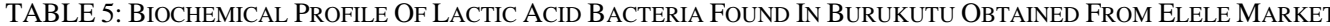

\begin{tabular}{|c|c|c|c|c|c|c|c|c|c|c|c|c|c|}
\hline Test \Isolate & 1 & 2 & 3 & 4 & 5 & 6 & 7 & 8 & 9 & 10 & 11 & 12 & 13 \\
\hline Shape of isolate & rods & rods & rods & rods & rods & rods & rods & rods & rods & rods & cocci & cocci & rods \\
\hline Tetrad formulation & - & - & - & - & - & - & - & - & - & - & - & - & - \\
\hline Gram stain & + & + & + & + & + & + & + & + & + & + & + & + & + \\
\hline Catalase & - & - & - & - & - & - & - & - & - & - & - & - & - \\
\hline Oxidase & - & - & - & - & - & - & - & - & - & - & - & - & - \\
\hline Anaerobic growth & + & + & + & + & + & + & + & + & + & + & + & + & + \\
\hline $\mathrm{CO}_{2}$ from glucose & + & - & - & - & - & + & - & + & + & + & - & - & + \\
\hline Nutrient broth, $\mathrm{pH} 4.4$ & + & + & + & + & + & + & + & + & + & + & - & - & + \\
\hline Nutrient broth, pH 9.6 & + & + & + & + & + & + & + & + & + & + & + & + & + \\
\hline Growth in $6.5 \% \mathrm{NaCl}$ & + & - & + & - & + & + & + & + & + & + & + & + & + \\
\hline Growth in $18 \% \mathrm{NaCl}$ & - & - & - & - & - & - & - & - & - & - & + & + & - \\
\hline Growth at $15^{\circ} \mathrm{C}$ & + & + & - & + & - & - & - & - & - & - & - & - & - \\
\hline Growth at $45^{\circ} \mathrm{C}$ & - & - & + & - & + & + & + & + & + & + & - & - & + \\
\hline Probable LAB & $\mathrm{E}$ & $\mathrm{F}$ & $\mathrm{G}$ & $\mathrm{F}$ & $\mathrm{G}$ & $\mathrm{H}$ & $\mathrm{G}$ & $\mathrm{H}$ & $\mathrm{H}$ & $\mathrm{H}$ & $\mathrm{I}$ & $\mathrm{I}$ & $\mathrm{H}$ \\
\hline
\end{tabular}

Key: E - Lactobacillus brevis; F - Lactobacillus plantarum; G - Lactobacillus acidophilus; H - Lactobacillus fermentum; I - Lactococcus lactis; LAB Lactic acid bacteria.

\begin{tabular}{|c|c|c|c|c|c|c|c|c|c|c|c|c|c|c|}
\hline TestlIsolate & 1 & 2 & 3 & 4 & 5 & 6 & 7 & 8 & 9 & 10 & 11 & 12 & 13 & 14 \\
\hline Shape & cocci & cocci & rods & rods & rods & rods & rods & rods & rods & rods & rods & cocci & cocci & rods \\
\hline Gram stain & + & + & + & + & + & + & + & + & + & + & + & + & + & + \\
\hline Catalase & - & - & - & - & - & - & - & - & - & - & - & - & - & - \\
\hline Oxidase & - & - & - & - & - & - & - & - & - & - & - & - & - & - \\
\hline Anaerobic growth & + & + & + & + & + & + & + & + & + & + & + & + & + & + \\
\hline Glucose & - & - & - & - & - & - & + & - & + & + & + & - & - & + \\
\hline Growth pH 4.4 & - & - & + & + & + & + & + & + & + & + & + & - & - & + \\
\hline Growth in $6.5 \% \mathrm{NaCl}$ & + & + & - & + & - & + & + & + & + & + & + & + & + & + \\
\hline Growth in $18 \% \mathrm{NaCl}$ & + & + & - & - & - & - & - & - & - & - & - & + & + & - \\
\hline Growth at $15^{\circ} \mathrm{C}$ & - & - & + & - & + & - & - & - & - & - & - & - & - & - \\
\hline Gowth at $45^{\circ} \mathrm{C}$ & - & - & - & + & - & + & + & + & + & + & + & - & - & + \\
\hline Galactos & + & + & + & + & + & + & + & + & + & + & + & + & + & + \\
\hline Lactose & + & + & + & + & + & + & + & + & + & + & + & + & + & + \\
\hline Arabinos & + & + & - & + & - & + & - & + & + & + & + & + & + & + \\
\hline Mannose & - & - & - & - & - & + & - & + & + & + & - & - & + & - \\
\hline Fructose & + & + & + & + & + & + & + & + & + & + & + & + & + & + \\
\hline Raffinos & + & + & + & + & - & - & - & - & - & - & - & - & - & + \\
\hline Probable LAB & $\mathrm{E}$ & $\mathrm{F}$ & $\mathrm{G}$ & $\mathrm{F}$ & $\mathrm{G}$ & $\mathrm{H}$ & $\mathrm{G}$ & $\mathrm{H}$ & $\mathrm{H}$ & $\mathrm{H}$ & $\mathrm{I}$ & $\mathrm{I}$ & $\mathrm{H}$ & $\mathrm{E}$ \\
\hline
\end{tabular}

Key: E - Lactobacillus brevis; F - Lactobacillus plantarum; G - Lactobacillus acidophilus; H - Lactobacillus fermentum; I - Lactococcus lactis; LAB Lactic acid bacteria.

\begin{tabular}{|c|c|c|c|c|c|c|c|c|c|c|c|c|}
\hline Test \Isolate & 1 & 2 & 3 & 4 & 5 & 6 & 7 & 8 & 9 & 10 & 11 & 12 \\
\hline Shape & cocci & cocci & rods & rods & rods & rods & rods & rods & rods & rods & rods & cocci \\
\hline Gram stain & + & + & + & + & + & + & + & + & + & + & + & + \\
\hline Catalase & - & - & - & - & - & - & - & - & - & - & - & - \\
\hline Oxidase & - & - & - & - & - & - & - & - & - & - & - & - \\
\hline Anaerobic growth & + & + & + & + & + & + & + & + & + & + & + & + \\
\hline $\mathrm{CO}_{2}$ from glucose & - & - & - & - & - & - & + & - & + & + & + & - \\
\hline Growth pH 4.4 & - & - & + & + & + & + & + & + & + & + & + & - \\
\hline Growth pH 9.6 & + & + & + & + & + & + & + & + & + & + & + & + \\
\hline Growth $6.5 \mathrm{NaCl}$ & + & + & - & + & - & + & + & + & + & + & + & + \\
\hline Growth in $18 \% \mathrm{NaCl}$ & + & + & - & - & - & - & - & - & - & - & - & + \\
\hline Growth at $15^{\circ} \mathrm{C}$ & - & - & + & - & + & - & - & - & - & - & - & - \\
\hline Growth at $45^{\circ} \mathrm{C}$ & - & - & - & + & - & + & + & + & + & + & + & - \\
\hline Probable LAB & I & I & $\mathrm{F}$ & G & $\mathrm{F}$ & G & $\mathrm{H}$ & G & $\mathrm{H}$ & $\mathrm{H}$ & $\mathrm{H}$ & I \\
\hline
\end{tabular}

Key: E - Lactobacillus brevis; F -Lactobacillus plantarum; G - Lactobacillus acidophilus; H - Lactobacillus fermentum; I - Lactococcus lactis; LAB Lactic acid bacteria.

Presented in Fig. 2 is the percentage frequency of occurrence of lactic acid bacteria (LAB) isolated from commercialized burukutu obtained from the three markets and the laboratory brewed burukutu. The LAB in commercialized burukutu obtained from Elele market which had the highest and least frequency of occurrence was Lactobacillus fermentum (38.46\%) and L. brevis $(7.69 \%)$, respectively. The percentage frequency of occurrence of LAB found in commercialized burukutu obtained from Rumuokoro market shows that Lactobacillus fermentum
(33.33\%) and L. plantarum (16.67\%) were the highest and least occurring specie of $\mathrm{LAB}$, respectively. As for the commercialized burukutu obtained from Choba market, the LAB isolate which had the highest and least percentage frequency of occurrence is Lactobacillus fermentum (35.71\%) and $14.29 \%$ each for Lactobacillus brevis and $L$. plantarum, respectively. Lactococcus lactis (20\%), Lactobacillus plantarum (10\%), L. fermentum (40\%) and L. acidophilus (30\%) were the LAB isolates obtained from the 
laboratory brewed burukutu and their respective percentage frequency of occurrence.

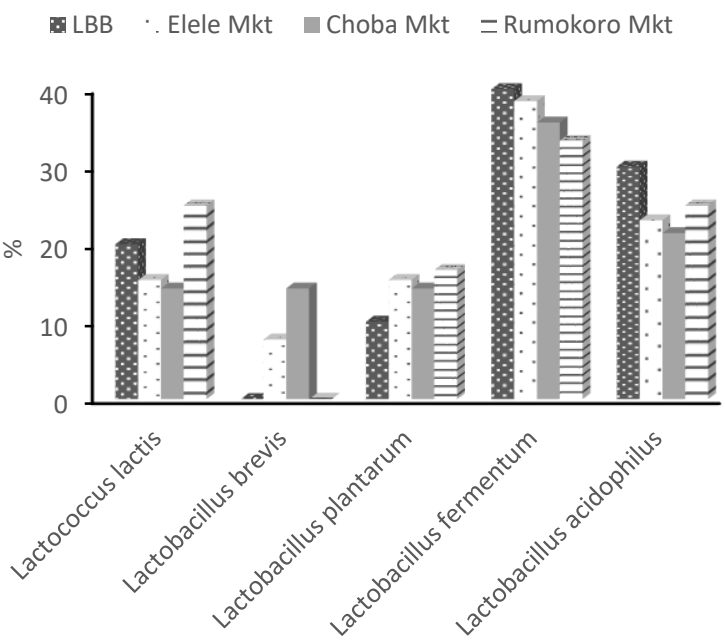

Microorganism

Fig. 2. Frequency of occurrence of lactic acid bacteria isolated from burukutu obtained from the three markets and the laboratory brewed burukutu (LBB).

Presented in Table 8 is the microscopic and macroscopic characteristics of yeast and moulds isolated from the laboratory brewed burukutu as well as a similar product obtained from the three markets. The result obtained showed that Saccharomyces cerevisiae, Aspergillus sp. and Mucor sp. were present in burukutu obtained from the markets. With the exception of Mucor sp., the other two fungal genera found in the commercialized burukutu were also present in the laboratory brewed burukutu.

TABLE 8: Fungal ISOLATES From BURUKuTU SAMPLED From THE THREE MARKETS AND LABORATORY BREWED BURUKUTU

\begin{tabular}{|c|c|c|c|}
\hline Sample & Macroscopy & Microscopy & Probable organism \\
\hline EM & $\begin{array}{l}\text { Creamy round } \\
\text { colonies }\end{array}$ & $\begin{array}{l}\text { Large cell globes } \\
\text { with budding }\end{array}$ & $\begin{array}{l}\text { Saccharomyces } \\
\text { cerevisiae }\end{array}$ \\
\hline \multirow{4}{*}{$\mathrm{CM}$} & Black colonies & $\begin{array}{c}\text { Septate hyphae with } \\
\text { budding }\end{array}$ & Aspergillus sp. \\
\hline & Black colonies & $\begin{array}{c}\text { Septate hyphae with } \\
\text { budding }\end{array}$ & Aspergillus sp. \\
\hline & $\begin{array}{l}\text { Creamy round } \\
\text { colonies }\end{array}$ & $\begin{array}{l}\text { Large cell globes } \\
\text { with budding }\end{array}$ & $\begin{array}{c}\text { Saccharomyces } \\
\text { cerevisiae }\end{array}$ \\
\hline & Black colonies & Spongy-like growth & Mucor sp. \\
\hline $\mathrm{RM}$ & $\begin{array}{c}\text { Creamy round } \\
\text { colonies }\end{array}$ & $\begin{array}{l}\text { Large cell globes } \\
\text { with budding }\end{array}$ & $\begin{array}{c}\text { Saccharomyces } \\
\text { cerevisiae }\end{array}$ \\
\hline \multirow{3}{*}{ LBB } & Black colonies & $\begin{array}{c}\text { Septate hyphae with } \\
\text { Budding }\end{array}$ & Aspergillus sp. \\
\hline & $\begin{array}{l}\text { Creamy round } \\
\text { colonies }\end{array}$ & $\begin{array}{l}\text { Large cell globes } \\
\text { with budding }\end{array}$ & $\begin{array}{c}\text { Saccharomyces } \\
\text { cerevisiae }\end{array}$ \\
\hline & Black colonies & $\begin{array}{l}\text { Septate hyphae with } \\
\text { Budding }\end{array}$ & Aspergillus sp. \\
\hline
\end{tabular}

Key: EM - Elele market; CM - Choba market; RM - Rumuokoro; LBB Laboratory brewed burukutu.

The $\mathrm{pH}$, titratable acidity, alcohol content, and soluble solids of laboratory brewed burukutu at different stages of the brewing process and the fermenting burukutu (finished product) is presented in Table 9. At the various stages of brewing burukutu, $\mathrm{pH}$ of the mash was as high as 7.0, that of supernatant (4.0) and sediment (3.9) were almost the same, but that of boiled wort was 3.7. It is interesting to note that $\mathrm{pH}$ of the fermenting burukutu ranging from 3.6-3.0 was steadily decreasing with increase in fermentation time. The titratable acidity at the various stages of brewing burukutu range from $0.00-0.10 \%$. The values decreased from 0.90 $0.70 \%$ in the course of fermentation but increased to $0.97 \%$ at the $48 \mathrm{~h}$. At the various brewing stages of burukutu, alcohol was not detected. The presence of alcohol was detected after $6 \mathrm{~h}$ of fermentation and increased to $4.7 \%$ after $48 \mathrm{~h}$ of fermentation. Table 9 shows that total soluble solids at the various stages of fermentation starting from the mash to the boiled wort increased from 0.65 to $0.90 \%$. During the $48 \mathrm{~h}$ fermentation period, the total soluble solids of the fermenting burukutu steadily increased from 0.90 to $0.99 \%$.

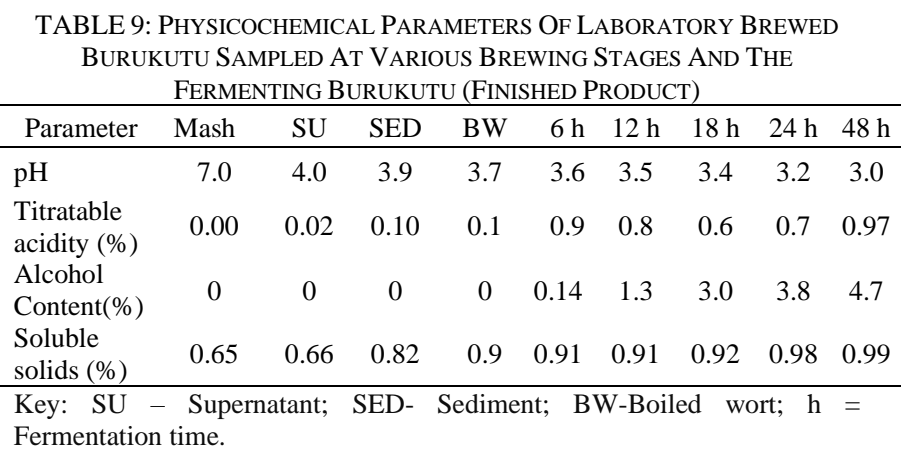

Depicted in Fig. 3 is the physicochemical parameters of commercialized burukutu obtained from the three markets and laboratory brewed burukutu (LBB) undergoing $48 \mathrm{~h}$ fermentation. The $\mathrm{pH}$ of burukutu obtained from Elele (EM) and Choba markets (CM) was 3.0 whereas a slightly higher $\mathrm{pH} 3.1$ was encountered in burukutu obtained from Rumuokoro market (RM). However, Analysis of variance indicated that there is no significant difference $(\mathrm{P}>0.05)$ between the $\mathrm{pH}$ of the commercial burukutu from the three markets. At $48 \mathrm{~h}$ during the fermentation period of the LBB, the $\mathrm{pH}$ of the final product was the same with the sample obtained from EM and CM after the value steadily decreased from 3.6 - 3.0. The titratable acidity (TA) of burukutu obtained from CM and RM was 0.02 and $0.1 \%$, respectively whereas TA was not detected in the commercialized burukutu obtained from EM. Data obtained indicated that there is significant difference $(\mathrm{P}<0.05)$ between the TA of the commercial burukutu from the three markets. Meanwhile, during the fermentation period of $\mathrm{LBB}$, the TA ranged between $0.6-0.97 \%$. The alcohol content of burukutu obtained from EM, CM and RM markets were $2.1,3.2$, and $4.0 \%$, respectively whereas the alcohol content of LBB undergoing $48 \mathrm{~h}$ fermentation steadily increased from $0.14-4.7 \%$. This result shows that alcohol content of the LBB (final product) at $48 \mathrm{~h}$ was higher than the values obtained from commercialized burukutu obtained from the three markets. There is significant difference $(\mathrm{P}<0.05)$ between the alcohol contents of the commercial burukutu from the three markets as well as LBB. Our result also shows that soluble solids present in the commercialized burukutu obtained from EM, CM, and RM were $0.65,0.66$ and $0.82 \%$, respectively. A slightly higher soluble solid within the range $0.90-0.99 \%$ was encountered in LBB undergoing $48 \mathrm{~h}$ fermentation. 


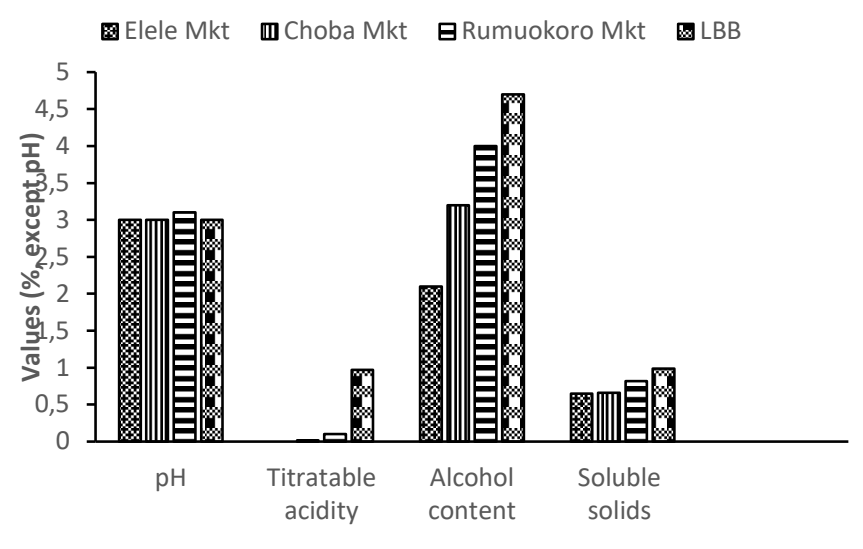

Physiocochemical Parameters

Fig. 3. Physicochemical properties of burukutu sampled from the three markets and laboratory-brewed burukutu (LBB).

Analysis of variance showed that there is no significant difference $(\mathrm{P}>0.05)$ between the soluble solids present in the commercial burukutu from EM and CM, but the values were significantly different from burukutu obtained from RM. The proximate composition of the laboratory brewed and the commercialized burukutu obtained from the three markets is presented in Fig. 4. The results show that the laboratory brewed burukutu had higher moisture $(52.1 \%)$, crude fat (15.7\%), crude protein $(7.6 \%)$ and ash content $(9.8 \%)$ compared with the commercialized burukutu obtained from the three markets. However, the laboratory brewed burukutu had the least carbohydrate content $(15.4 \%)$.

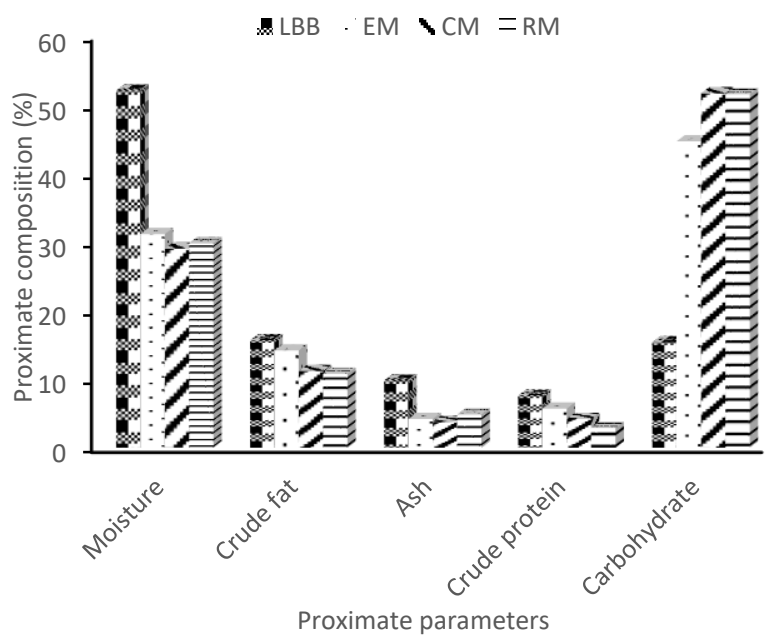

Fig. 4. Proximate composition of laboratory brewed and commercialized burukutu sampled from three markets.

Key: LBB = Laboratory brewed burukutu; EM- Elele market; CM- Choba market; RM - Rumuokoro market.

The level of mineral element (ppm) in the laboratory brewed and the commercialized burukutu obtained from the three markets is presented in Table 10. The results obtained showed that potassium (1.2 ppm), calcium (4.5 ppm), sodium (3.1 ppm), zinc (4.32 ppm) and magnesium $(4.5 \mathrm{ppm})$ content in the laboratory brewed burukutu is higher than the values obtained for each of the minerals present in the commercialized burukutu obtained from the three markets. However, the level of phosphorus (3.2 ppm) in the laboratory brewed burukutu and similar samples obtained from the markets were the same except burukutu obtained from Elele market which was $3.1 \mathrm{ppm}$. Meanwhile, the iron content $(3.1 \mathrm{ppm})$ of burukutu from Elele market is higher than the values detected in the products obtained from Choba and Rumuokoro markets including the laboratory brewed burukutu. The analysis of variance conducted revealed that all the minerals with the exception of phosphorus in the LBB reported in this study were significantly different $(\mathrm{p}<0.05)$ from the values obtained in burukutu from the three markets. However, the calcium, potassium, and iron content of burukutu from Rumuokoro and Choba markets are not significantly significant $(\mathrm{p}>0.05)$.

TABLE 10: Minerals CONTENT OF THE LABORATORY BREWED AND COMMERCIALIZED BURUKUTU OBTAINED FROM THE THREE MARKETS

\begin{tabular}{cccccccc}
\hline Sample & \multicolumn{7}{c}{ Minerals (ppm) } \\
\hline & $\mathrm{K}$ & $\mathrm{Ca}$ & $\mathrm{Na}$ & $\mathrm{Fe}$ & $\mathrm{Zn}$ & $\mathrm{Mg}$ & $\mathrm{P}$ \\
\hline LBB & 1.2 & 4.5 & 3.1 & 2.22 & 4.32 & 4.5 & 3.2 \\
RM & 1.1 & 4.0 & 3.0 & 2.1 & 3.5 & 3.5 & 3.1 \\
CM & 1.1 & 3.9 & 2.9 & 2.0 & 2.5 & 3.1 & 3.2 \\
EM & 1.0 & 2.5 & 2.5 & 3.1 & 3.2 & 3.2 & 3.2 \\
\hline
\end{tabular}

Key: LBB - Laboratory brewed burukutu; RM - Rumuokoro market; CM Choba market; EM- Elele market; ppm - parts per million.

\section{DISCUSSION}

This study showed that the increase in microbial count occurred at the early stages of the brewing process during the production of burukutu. According to [3], this trend could be as a result of favourable growth condition and availability of nutrients for the microorganisms. In a related study, [25] reported high microbial count for aerobic mesophiles, yeasts, lactic acid bacteria, coliforms and Escherichia coli in sorghum grains, malted grains, supernatant, sediment, sourced wort, concentrated wort and old brew used for backslopping during processing of sorghum for the production of burukutu. According to their findings, coliforms such as E. coli disappeared when wort was boiled and this is consistent with the findings from this present study. The sorghum used in brewing the alcoholic beverage in the laboratory could be a source of various microorganisms encountered during the earlier processing stages of burukutu. In a related study, [26] reported total aerobic plate count (7.11-8.76 $\left.\log _{10} \mathrm{CFU} / \mathrm{ml}\right), \mathrm{LAB}$ count (6.80-8.76 $\left.\log _{10} \mathrm{CFU} / \mathrm{ml}\right)$, fungal count (4.43-6.85 $\left.\log _{10} \mathrm{CFU} / \mathrm{ml}\right)$, and coliform count (4.20-5.95 $\log _{10} \mathrm{CFU} / \mathrm{ml}$ ) in malted sorghum prepared using a standardized procedure which were higher than 5.5 $\log _{10} \mathrm{CFU} / \mathrm{ml}$, 4.67 $\log _{10} \mathrm{CFU} / \mathrm{ml}, 4.43 \log _{10} \mathrm{CFU} / \mathrm{ml}$ and $3.26 \mathrm{Log}_{10} \mathrm{CFU} / \mathrm{ml}$, respectively in the unmalted sorghum. In order to reduce the population of coliforms and moulds present in the malted sorghum, [27] researched on the effect of using bacterial (Lactobacillus plantarum, Pedioccocus pentosaceus) and yeast starter (Saccharomyces sp.) culture instead of chemical treatments. Findings from the study revealed that population of coliforms, and moulds reduced during malting of sorghum incorporated with the bacterial and yeast starter culture.

A comparison between the microbial count of the fermenting burukutu and the samples collected earlier at various stages of the brewing process is an indication that the accumulation of organic acid and increase in alcohol content during the fermentation process created an 
unfavourable environment for the microorganisms to thrive. This condition may also have contributed significantly in reducing the population of lactic acid bacteria (LAB) from 9.11-3.61 $\log _{10} \mathrm{Cfu} / \mathrm{ml}$, faecal coliforms from 7.52 $\log _{10} \mathrm{Cfu} / \mathrm{ml}$ to a safe level (absence of faecal coliforms) in the fermenting burukutu. Meanwhile, aerobic mesophiles, total coliforms and fungi were not detected in the product. Microbiological analysis of boiled wort compared with sorghum mash before boiling, supernatant before boiling and sediment before boiling suggests that boiling of the wort eliminated microorganisms which could contaminate the final product (burukutu). In a related study, [3] noted that Escherichia coli and Staphylococcus aureus detected during early stages of the fermentation process of burukutu disappeared during the final preparation stages of burukutu which they suggested could be as a result of low $\mathrm{pH}$ (approximately 3.5) and increased acidity in the malted grains. At that stage, the release of hydrogen peroxide and other antimicrobial agents by Lactobacillus sp. which is the dominant bacterial genera could either kill or inhibit the growth of other microorganisms.

The overall result of the microbial analysis of burukutu sampled from three markets namely, Elele (EM), Choba (CM) and Rumuokoro (RM) revealed that the alcoholic beverage purchased from $\mathrm{CM}$ had a slightly higher microbial count compared with samples of burukutu obtained from EM and RM. Interestingly, microbiological analysis of the laboratory brewed burukutu (LBB) showed that $\mathrm{LAB}$ count 3.61 and $3.70 \log _{10} \mathrm{Cfu} / \mathrm{ml}$ was present in the alcoholic beverage at 24 and $48 \mathrm{~h}$ fermentation period whereas aerobic mesophilic bacteria, coliforms and fungi were not detected in the product. This is possibly as a result of aseptic techniques involved in the brewing process in a laboratory-controlled environment. According to [4], LAB isolated from burukutu possess antimicrobial properties against Staphylococcus aureus and Escherichia coli.

The limit for mesophilic aerobic count for fermented foods and beverages considered safe for consumption as recommended by the National Agency for Food and Drug Administration and Control (NAFDAC) is $5 \log _{10} \mathrm{CFU} / \mathrm{ml}$ [28]. Therefore, all the samples of commercialized burukutu from the three markets which range from 6.92-7.96 $\log _{10} \mathrm{CFU} / \mathrm{ml}$ are not safe for human consumption since they did not meet the NAFDAC requirement. Generally, aerobic mesophilic counts serve as a good indicator to evaluate the overall quality of a production process. In a related study, Falegan and Akoja [29], reported that burukutu sold in some locations in Ekiti state is not safe for human consumption due to presence of Listeria sp., Acetobacter spp., and Corynebacterium spp. Interestingly, the sample of burukutu brewed in our laboratory met the NAFDAC requirement in terms of mesophilic aerobic count which certifies the product safe for human consumption. According to World Health Organization (WHO), in any $100 \mathrm{ml}$ sample of water for drinking, there must be absence of Escherichia coli and thermotolerant coliform bacteria [30]. Poor personal hygiene, unsanitary environment, the use of contaminated raw materials, utensils, storage cans and water could be responsible for high microbial count of commercialized burukutu sampled from CM, EM and RM unlike a similar alcoholic beverage brewed in a laboratory using aseptic techniques in a hygienic environment.

Enterobacter aerogenes, Escherichia coli and Staphylococcus aureus were identified from samples of burukutu obtained from the markets. This result partially agrees with a similar study carried out by [14], [10] which reported the presence of E. coli and $S$. aureus in burukutu. In a related study, [15] found Enterobacter aerogenes in burukutu sold in Abakpa market. This bacterium is associated with urinary tract infections and hospitalacquired infections. It is widely distributed in animals and humans. Enterobacter aerogenes can also be found in sewage, soil, and water. In beer brewing process, this bacterium is known to contaminate the fermented wort [31]. The presence of $E$. coli which is a common faecal coliform in burukutu obtained from the three markets suggests that the product was exposed to unsanitary conditions during the brewing process and handling of the final product. The major raw material (sorghum) for brewing burukutu could also be a source of contamination. Exposure of burukutu to flies, the use of contaminated water and unsterilized utensils could also be a source of microbial contamination of the product [15]. Escherichia coli forms part of the normal flora of the intestine of humans and other vertebrates. The presence of $E$. coli in burukutu poses a threat to public health [14]. Diarrhea in children and infants, gastroenteritis and urinary tract infection are caused by certain strains of Escherichia coli [15]. Brewing burukutu in a hygienic environment, decontamination of the raw materials involved, and the use of potable water could prevent contamination of the product with $E$. coli. Result from this study shows that $S$. aureus was present in burukutu obtained from the three markets but it was not detected in the laboratory brewed burukutu. Isolation of $S$. aureus from samples of burukutu sold in the three markets could be as a result of poor personal hygiene of the processors. Since $S$. aureus is part of a normal flora of human skin, the possibility of contaminating burukutu is high unless aseptic technique is adopted during the production process [14]. $S$. aureus is a leading cause of staphylococcal food poisoning which manifest symptoms such as vomiting and diarrhea. Majority of those that produce burukutu at the cottage level use unwashed bare hands and wooden paddles. Sometimes, when the product is allowed to stand in the course of brewing burukutu, it is left uncovered and dusty air could contaminate the product with pathogenic microorganisms [32].

Fungi isolated at the various brewing stages of burukutu were Saccharomyces cerevisiae and Aspergillus sp. A related study carried out by [15] also reported the presence of $S$. cerevisiae and Aspergillus sp. in burukutu sold in mammy market, Abakpa, Enugu State, Nigeria. Both fungal genera were also found in samples of burukutu obtained from the three markets namely Elele (EM), Rumuokoro (RM) and Choba (CM). In addition, Mucor sp. was also identified in the samples obtained from CM. This is in agreement with [32] which reported the presence of Mucor sp. in a commercially brewed burukutu. The result obtained from this study showed that Saccharomyces cerevisiae was the dominant yeast in the samples of commercialized 
burukutu analysed. This observation collaborates the findings of [25] in a related study.

Lactic acid bacteria (LAB) were found in all samples of burukutu, both laboratory brewed burukutu and commercialized burukutu obtained from the three markets. The LAB comprises of Lactococcus lactis, Lactobacillus fermentum, L. acidophilus, L. plantarum and L. brevis. All the LAB isolates from burukutu were also reported by [25] from a related study. This confirms that brewing African traditional beer involves lactic acid fermentation. A close association between yeast and lactic acid bacteria in many cereal foods has been previously reported. Yeast is known to provide soluble nitrogen compounds as well as other growth factors which stimulate the growth of LAB. In the production of kefir, carbon (IV) oxide, propionate, pyruvate, succinate and acetate which are yeast metabolites stimulate activities of lactobacilli [3], [15]. The dominance of Lactobacillus fermentum among the lactic acid bacteria (LAB) isolated from commercialized burukutu sampled from Elele, Choba and Rumuokoro markets collaborates the report from a related study carried out by [25] which also reported the presence of $L$. acidophilus, L. brevis, Lactococcus lactis subsp. lactis in burukutu. Different researchers have also reported the presence of these LAB in various traditional beers.

The $\mathrm{pH}$ of the laboratory brewed burukutu ranged from 3.0-3.4 whereas that of commercialized burukutu obtained from the three markets ranged from 3.0-3.1. According to [33], the $\mathrm{pH}$ of burukutu based on its basic characteristics should be within the range of 3.3-3.5. The result obtained from this study implied that this requirement was met by the laboratory brewed burukutu whereas the commercialized samples from the three markets did not meet the requirement. In a related study, [32] reported that $\mathrm{pH}$ of laboratory brewed burukutu (LBB) and commercially brewed burukutu was 3.9 and 3.8, respectively which is higher than the values reported in this study. According to [1], the variations in alcohol content of LBB (0.14-4.7\%) undergoing $48 \mathrm{~h}$ fermentation and commercialized burukutu $(2.1-4.0 \%)$ from the three markets could be as a result of influence from the environment and variations in the processing methods. Several studies have identified Saccharomyces cerevisiae as the yeast that brings about alcoholic fermentation in burukutu [25]. The alcohol content of the laboratory brewed burukutu $(4.7 \%)$ at $48 \mathrm{~h}$ is higher when compared with the commercialized samples obtained from the three markets. According to [12], the alcohol content of burukutu is usually within the range of 3-6\%. The alcohol content of both LBB and commercialized burukutu falls within that range. The level of some alcoholic beverages including burukutu in the urine after consumption was investigated by [34]. Findings from the study revealed that concentration of alcohol in burukutu was $3.2(\% \mathrm{v} / \mathrm{v})$ whereas the level of alcohol in the urine of the subjects that consumed the alcoholic beverage was $120 \mathrm{mg} / \mathrm{dL}$ while 89 $\mathrm{mg} / \mathrm{dL}$ was the estimated blood concentration. Since the subjects consumed burukutu on empty stomach, $4.69 \%$ of the administered dose was excreted in the urine. It was envisaged that the consumers will experience mild influence on stereoscopic vision and lack of adaptation. Notably, the subjects that consumed burukutu were not legally drunk based on blood alcohol level not exceeding $100 \mathrm{mg} / \mathrm{dL}$ approved by most countries. After investigating the effect of burukutu on redox status of the liver of male rats, [12] in their report warned against indiscriminate consumption of burukutu which could affect their health and wellbeing.

Atter et al. [25] in another related study which involves the production of burukutu reported that the $\mathrm{pH}$, titratable acidity (TA), soluble solids and alcohol content of the product were within the ranges of 2.88-3.36, 0.54-0.82\%, $3.33-7.50 \%$, and $0.99-4.47 \%$, respectively. These values are in agreement with the result obtained from this study with the exception of soluble solids which is higher than the values reported in Table 9 and Fig. 3. The increase in titratable acidity and reduction in $\mathrm{pH}$ of burukutu as fermentation time increased shows that souring/acidification is a crucial activity that occurs during production of burukutu [25]. Our results revealed that TA of laboratory brewed burukutu within the fermentation period range from $0.6-0.97 \%$ is higher than TA of the commercialized product $(0-0.1 \%)$ obtained from the three markets. Higher TA in the laboratory brewed burukutu could be as a result of acetic acid formed when carbon (IV) oxide was oxidized due to duration of fermentation [35].

The protein content of laboratory brewed burukutu was $7.6 \%$. This value is higher than protein content of commercialized burukutu obtained from the three markets which ranged between 2.9-5.7\%. The variation in protein content could be as a result of varieties of sorghum used for preparing burukutu. The protein content of commercialized burukutu reported in this study is a thing of concern considering high level reliance of the alcoholic beverage by millions of impoverished individuals as a meal. Our study has shown that protein content in all the samples of burukutu sampled from the three markets as well as the laboratory-brewed burukutu is below the lower limit of the recommended dietary reference intake's (DRI) acceptable macronutrient distribution range (AMDR) of 10-35\% protein for adults. In a related study, [2] reported higher protein content of $15.14 \%$ in burukutu, hence, not in agreement with our observation. High protein content of burukutu reported by [2] could be as a result of adding maize to sorghum to serve as a raw material for the production of the alcoholic beverage which was not the case in our study.

All body activities such as proper functioning of kidneys, brain, muscles and nervous systems require energy from carbohydrate. Result from this study indicated that the carbohydrate content of commercialized burukutu sampled from the three markets range from $44.7-51.7 \%$ which is within the DRI's AMDR range (45-65\%) of energy derived from carbohydrate for adults. However, a lower carbohydrate content $(15.4 \%)$ reported in the laboratory brewed burukutu did not meet the criteria. Surprisingly, [4] reported a lower carbohydrate content of $3.52 \mathrm{~g} / 100 \mathrm{~g}$ and $8.38 \mathrm{~g} / 100 \mathrm{~g}$ in fermented and unfermented burukutu, respectively. According to [36], consuming diets any of the macronutrients (protein, fat, and carbohydrate) falls outside the AMDR is considered unhealthy. Since alcohol consumption contribute to dietary energy, consuming the LBB as a regular meal might not provide adults adequate quantity of calories needed for proper functioning of the 
human body [37]. Interestingly, several studies have suggested that consumption of low carbohydrate diets will help diabetic patients to manage their body weight, improve glycemic control and reduce fluctuations in insulin level [38]. Meanwhile, [39], reported a carbohydrate content of $82.85 \%$ and $76.22 \%$ in fresh and stored burukutu, respectively which exceeded the DRI's AMDR range.

Fat helps in the maintenance of cell membrane, functions as an insulator for the body, useful for growth and development. It serves as a source of energy to the human body as well as a solvent for vitamin A, D, E and K. Fat also provide taste and consistency in foods. Based on the DRI's AMDR recommendation for total fats in adults which ranges from $25-35 \%$, our result showed that fat content of the laboratory brewed burukutu which was $15.7 \%$ and commercialized burukutu sampled from the three markets ranging from $10.8-14.2 \%$ did not meet the requirement.

In humans, moisture is required for good health and enhances physiological processes such as digestion of food materials, absorption of the nutrients in food, and oxygen supply to the cells. Moisture also helps in the removal of waste from the human body [2]. The moisture content of laboratory brewed burukutu which was $52.1 \%$ partially agree with the result reported by [2] which involved the production of sorghum based burukutu, millet based burukutu, maize based burukutu and composite of sorghum, millet and maize which had 55.50\%, 55.69\%, 55.06\% and $55.64 \%$, respectively as their moisture contents. The commercialized samples of burukutu obtained from Elele, Rumuokoro and Choba markets had lower moisture content which ranged from $29.9-31.2 \%$. The variations in moisture content could be as a result of the different procedures adopted by the local processors in brewing burukutu.

The mineral content of burukutu sampled from the three markets range from $3.8-4.85 \%$. Higher ash content $(9.8 \%)$ in the laboratory brewed burukutu suggests that the alcoholic beverage contains higher levels of minerals compared with a similar product sampled from the three markets. The variations in proximate composition of the commercially brewed burukutu and laboratory brewed burukutu could be as a result of the quality of sorghum used and processing methods adopted. Environmental factors which includes soil moisture, soil fertility and cultural practices as well as genetic factors could also influence the nutrient composition of sorghum [32]. In food analysis, ash content is an index of mineral element composition of food samples.

Intake of minerals is important to the human body because it helps in regulating and building the living cells as well as help fight depression [15]. Iron constitute a major functional component of the haemoglobin of red blood cells and myoglobin in the muscles responsible for distributing oxygen throughout the body. Healthier cardiovascular system and maintenance of water homeostasis essential for life processes is aided by magnesium. Calcium plays an important role in the formation of bones and teeth as well as help maintain normal blood pressure and impulse transmission [1]. Mineral analysis of laboratory brewed burukutu reported by [32] showed that magnesium, calcium and iron content were $116 \mathrm{ppm}, 1.58 \mathrm{ppm}$ and $11.90 \mathrm{ppm}$, respectively whereas figures from commercially brewed burukutu were $114 \mathrm{ppm}, 1.58 \mathrm{ppm}$, and $21.10 \mathrm{ppm}$, respectively. Eze et al. [15] in a related study reported that the mean calcium, iron, magnesium, phosphorus, potassium and sodium content of burukutu sold in Abakpa, Enugu State, Nigeria were $1.47 \%, 12 \%, 32 \%, 0.61 \%, 1.08 \%$ and $1.41 \%$, respectively. According to [4], zinc, phosphorus and iron content of burukutu fermented for $120 \mathrm{~h}$ was 4.00 $\mathrm{mg} / \mathrm{L}, 40.75 \mathrm{mg} / 100 \mathrm{~g}$ and $2.23 \mathrm{mg} / 100 \mathrm{~g}$, respectively. According to World Health Organization (WHO), safe limit of zinc in potable water is $3 \mathrm{mg} / \mathrm{L}$. In alcohol, the permissible limit of zinc is $5.0 \mathrm{mg} / \mathrm{L}$ [35]. This requirement was met by all the samples of burukutu analysed in this study. According to [4], the level of iron and zinc in grains is improved as a result of malting. It is also suggested that solubilisation of minerals in the container by the fermenting product could bring about increase in mineral content of the product. Considering the amount of minerals present in the samples of burukutu, it is interesting to note that potassium content is higher than sodium content which makes it a suitable diuretic diet for the prevention of hypertension [2]. The Standard Organization of Nigeria (SON) stipulate that permissible limit of $\mathrm{Fe}$ in drinking water is $0.3 \mathrm{mg} / \mathrm{L}$. The dietary allowance for $\mathrm{Fe}$ which is recommended for every individual is $10-18 \mathrm{mg} /$ day. For healthy adult males and females, the recommended dietary allowance (RDA) for $\mathrm{Mg}$ is $400-420$ and $310-320 \mathrm{mg} /$ day, respectively. The RDA for $\mathrm{Ca}$ is $1000 \mathrm{mg} \mathrm{Ca} /$ day [5]. According to [1], individuals that consume burukutu brewed using sorghum grains as the only cereal are likely to derive more health benefits associated with the intake of minerals compared with burukutu brewed using sorghum combined with corn and millet.

\section{CONCLUSION}

At the early stages of the brewing process of burukutu in the laboratory before boiling the wort, increase in the mean microbial count of aerobic mesophiles (6.62-9.7 $\log _{10} \mathrm{CFU} / \mathrm{ml}$ ), total coliforms (5.73-7.8 $\left.\log _{10} \mathrm{CFU} / \mathrm{ml}\right)$, faecal coliforms (5.23-7.52 $\left.\log _{10} \mathrm{CFU} / \mathrm{ml}\right)$, fungi (3.36-6.34 $\left.\log _{10} \mathrm{CFU} / \mathrm{ml}\right)$ and Lactic acid bacteria (LAB) [(1.37-9.11 $\left.\left.\log _{10} \mathrm{CFU} / \mathrm{ml}\right)\right]$ were observed. The bacterial isolates identified were Lactobacillus sp., Lactococcus sp., Escherichia coli, whereas the fungal isolates were Saccharomyces cerevisiae and Aspergillus sp. However, during laboratory fermentation of the finished product (burukutu), only LAB within the range of 3.61-3.70 $\log _{10} \mathrm{CFU} / \mathrm{ml}$ ) were encountered. The total bacterial count (TBC), total fungal count (TFC), total coliform count (TCC), faecal coliform (FC) and LAB count of the commercialized burukutu obtained from Elele market (EM) were 7.01, 7.96, 7.0, 7.08 and 7.14 $\log _{10} \mathrm{CFU} / \mathrm{ml}$; from Rumuokoro market (RM) were 6.99, 6.92, 7.96, 7.08 and $7.11 \log _{10} \mathrm{CFU} / \mathrm{ml}$; from Choba market (CM) were 7.95, 7.90, 7.94, 7.04 and $7.13 \log _{10} \mathrm{CFU} / \mathrm{ml}$, respectively. Staphylococcus aureus, Escherichia coli, Saccharomyces cerevisiae, and Aspergillus sp. were found in both laboratory- brewed burukutu (LBB) and commercialized burukutu obtained from the three markets. Also, Enterobacter aerogenes and Mucor sp. were encountered in the commercialized burukutu. The LAB identified from the alcoholic beverage were Lactococcus lactis, Lactobacillus 
brevis, L. plantarum, L. fermentum and L. acidophilus. Among the LAB identified from both LBB and commercialized burukutu, Lactobacillus fermentum and $L$. brevis had the highest (33.33-40\%) and least (0-14.29\%) frequency of occurrence, respectively. The range of alcohol content (2.10-4.00\%) and $\mathrm{pH}(3.0-3.1)$ in the commercialized burukutu falls within the range of $0.4-4.7 \%$ and 3.0-3.6, respectively encountered in the fermenting LBB. However, titratable acidity and soluble solids of both LBB and commercialized burukutu did not follow the trend. The proximate composition of LBB falls outside the ranges encountered in the commercialized burukutu obtained from the three markets. The level of mineral elements in the LBB were higher than what was obtainable in the commercialized samples with the exception of iron $(\mathrm{Fe})$ content. The overall results from this study revealed that the LBB had less alcohol content, higher level of minerals, better microbial quality and nutritional composition compared with the commercialized burukutu sampled from Elele, Rumuokoro and Choba markets. Also, the laboratory brewed burukutu is considered safe for human consumption unlike the commercialized burukutu which is not safe based on the microbiological qualities. Although pasteurization of indigenous sorghum beer (burukutu) seem to be less attractive, it should be encouraged alongside other good manufacturing practices (GMP) and good hygienic practices (GHP) to guarantee microbial safety of the commercialized products.

\section{REFERENCES}

[1] E. C. Stephen, C. D. U. Nwokwu, and K. Bashir. (June 2017). Comparative physico-chemical analysis of locally brewed beer (burukutu) from corn, millet and sorghum. Am. J Sci. Tech. [Online]. 4(3). pp. 43-48. Available: http://www.aascit.org/journal/ajst.

[2] A. C. Ogbonna, C. I. Abuajah, and I. A. Umanah. (July 2016). Burukutu: healthy and superior indigenous African traditional opaque beverage. Am. J Adv. Food Sci. Tech. [Online]. 4(1). pp. 29-37. doi:10.7726/ajafst.2016.1004.

[3] A. B. Yusuf, B. H. Gulumbe, Z. M. Kalgo, B. Aliyu, and M. Haruna. (May 2020). Microorganisms associated with the production of burukutu (an alcoholic beverage) in Kebbi State, Nigeria. Equity $J$ Sci. Tech. [Online]. 7(1). pp. 67-73. Available: www.equijost.com.

[4] A. Atter, K. Obiri-Danso, G. A. Anyebuno, and W. K. Amoa-Awua. (July 2017). Effect of fermentation on the chemical quality of burukutu a traditional beer in Ghana. Annals, Food Sci. Tech. [Online].18(3). pp. 349-354. Available: www.afst.valahia.ro.

[5] C. M. A. Iwegbue, A. L. Ojelum, and F. I. Bassey. (June 2014). A survey of metal profiles in some traditional alcoholic beverages in Nigeria. Food Sci. Nutri. [Online]. 2(6). pp. 724-733. doi:10.1002/fsn3. 163.

[6] E. Evera, A. Abdallah, S. He, Z. Shuang, W. Sainan, and H. Yu. (2019). Shelf life and nutritional quality of sorghum beer: potentials of phytogenic-based extracts. J Agric. Food Tech. [Online]. 9(2). pp. 1-14. Available: www.textroad.com.

[7] C. K. Egemba, and V. E. Etuk. (2007). A Kinetic Study of Burukutu Fermentation. J Engineer. App. Sci. [Online]. 2(7). pp. 1193-1198.

[8] S. T. Ogunbanwo, A. O. Adewara, and P. T. Fowoyo. (2013). Effect of fermentation by pure cultures of Lactobacillus fermentum 1 and Saccharomyces cerevisiae as starter cultures in the production of burukutu. New York Sci. J. [Online]. 6(1). pp. 73-81. Available: http://www.sciencepub.net/newyork.

[9] M. N. Alo, U. A. Eze, and N. E. Eda. (2012). Microbiological qualities of burukutu produced from a mixture of sorghum and millet. Am. J Food Nutri. [Online]. 2(4). pp. 96-102. doi:10.5251/ajfn.2012.2.4.96.102. Available: http://www.scihub.org/AJFN

[10] O. O. Oladipo, A. B. Saanu, A. B. Juliet, and I. O. Adebola. (2018). Microbiological evaluation and antibiotic susceptibility pattern of bacteria associated with burukutu, a non-alcoholic beverage. J Food Res. Sci. [Online]. 7(1). pp. 1-7. doi: 10.3923/jfrs.2018.1.7.

[11] I. J. Sunday, and I. I. Aondover. (2013). Development of equations for estimating energy requirements in processing local alcoholic beverage (burukutu) in Nigeria. Int. J Engineer. Resear. Appli. [Online]. 3(4). pp. 648-654. Available: www.ijera.com.

[12] T. O. Ajiboye, G. A. Iliasu, O. B. Ojewuyi, A. T. Abdulazeez, A. O. Muhammed, and F. L. Kolawole. (May 2014). Sorghum-based alcoholic beverage, burukutu, perturbs the redox status of the liver of male rats. Food Sci. Nutri. [Online]. 2(5). pp. 591-596. doi: $10.1002 /$ fsn3.139.

[13] O. O. Olaniyi, and J. B. Akinyele. (July 2019). Isolation of toxigenic Aspergillus flavus and evaluation of aflatoxins in burukutu, sorghum fermented beverage sold in Akure, Nigeria. J Food Safe Hyg. [Online]. 5(1). pp. 30-38. Available: http://jfsh.tums.ac.ir.

[14] C. G. Anaukwu, F. C. Nwangwu, O. I. Okafor, C. C. Ezemba, C. C. Orji, K. C. Agu, and E. J. Archibong. (2015). Microbiological analysis of burukutu beverage produced in southern part of Nigeria. Eur. J Exp. Biol. [Online]. 5(8). pp. 18-22. Available: www.pelagiaresearchlibrary.com.

[15] V. C. Eze, O. I. Eleke, and Y. S. Omeh. (2011). Microbiological and nutritional qualities of burukutu sold in mammy market Abakpa, Enugu State, Nigeria. Am. J Food Nutri. [Online]. 1(3). pp. 141-146. doi:10.5251/ajfn.2011.1.3.141.146, http://www.scihub.org/AJFN.

[16] D. H. Larone. Medically important fungi, a guide to identification. Hagerston, Maryland, USA, London, Harper and Row. 1976, Vol. 2.

[17] D. Frey, R. J. Old-Field, and R. C. Bridjer. A colour atlas of pathogenic fungi. Wolf Medical Public Ltd. London. 1979.

[18] R. A. Samson, E. S. Hockstra, J. C. Frisvad, and D. Filtenburg D. Introduction to food borne fungi. Central bureau. Voor schimnel culture, Baarn Delft. Printed by Ponsen and Looyen. Wagening, the Netherlands. $1995,4^{\text {th }}$ edition.

[19] J. Dvorak, and M. Atanasek. Mycological diagnosis of animal dermatophytosis. Academic press 1969, pp. 213.

[20] Bergey's Manual of Determinative Bacteriology. Holt, J.D. (Ed.) Williams Wilkins CO. Baltimore, 1994, $9^{\text {th }}$ edition.

[21] M. Cheesbrough. District Laboratory Practice in Tropical Countries. Cambridge University Press, United Kingdom, 2005, $2^{\text {nd }}$ edtion.

[22] J. C. de Man, M. Rogosa, M. E. Sharpe. (1960). A medium for the cultivation of lactobacilli. J Appli. Bacteriology. 23. pp. 130-135.

[23] AOAC (1990). Methods of Analysis of the Association of Official Analytical Chemists. Arlington: Association of Official Analytical Chemists, Incorporated. $15^{\text {th }}$ edition. Vol. 2. pp. 739-750.

[24] AOAC (2005). Official Methods of Analysis. Association of Official Analytical, Chemists International, Maryland, USA. $18^{\text {th }}$ edition.

[25] A. Atter, K. Obiri-Danso, and W. K. Amoa-Awua. (April 2014). Microbiological and chemical processes associated with the production of burukutu a traditional beer in Ghana. Int. Food Resear J. [Online]. 21(5). pp. 1769-1776. Available: http://www.ifrj.upm.edu.my.

[26] M. L. Lefyedi, G. J. Marias, M. F. Dutton, and J. R. N. Taylor (2005). The microbial contamination, toxicity and quality of turned and unturned outdoor floor malted sorghum. J. Institute Brewing. [Online]. 111(2). pp. 190-196.

[27] M. L. Lefyedi, and J. R. N. Taylor. (2007). Control of the growth of coliforms and moulds in sorghum malting by bacterial and yeast cultures. The Institute Brewing Distilling. [Online]. 113(2). pp. 123 129.

[28] M. Umar, I. B. Mohammed, I. M. Abdulkarim, G. Yusuf, A. A. Yaya, and G. Leo. (March 2016). Comparative studies on the prevalence of Salmonella species in two homemade fermented beverages (zobo and kunu-zaki) sold at Samaru, Zaria, Kaduna, Nigeria. Int. J Sci. Resear. Pub. [Online]. 6(3). pp. 428-435. Available: www.ijsrp.org.

[29] C. R. Falegan, and S. O. Akoja. (2014). Microbiological and physicochemical studies of two Nigerian fermented alcoholic drinks (palm wine and burukutu) in Ekiti state, Nigeria. Eur. J Food Sci. Tech. [Online]. 2(2). pp. 13-22. Available: www.eajournals.org.

[30] I. E. Mbaeyi-Nwaoha, and N. I. Egbuche. (August 2012). Microbiological evaluation of sachet water and street-vended yoghurt and zobo drinks sold in Nsukka metropolis. Int. J Bio. Chem. Sci. [Online]. 6(4). 1703-1717. pp. Doi: http://dx.doi.org/10.4314/ijbcs.v6i4.27. Available: http://ajol.info/index.php/ijbcs.

[31] D. Matoulková, E. Vontrobová, M. Brožová, and P. Kubizniaková. (2018). Microbiology of brewery production-bacteria of the order Enterobacterales. Kvasny Prum. [Online]. 64(4). pp. 161-166. DOI: $10.18832 / \mathrm{kp} 201824$.

[32] O. M. Kolawole, R. M. O. Kayode, and B. Akinduyo. (March 2007). Proximate and microbial analyses of burukutu and pito produced in 
Ilorin Nigeria. Afri. J Biotech. [Online]. 6(5). pp. 587-590. Available: http://www.academicjournals.org/AJB.

[33] A. O. Adewara, and S. T. Ogunbanwo. (2013). Effects of processing variables on the production of burukutu, a Nigerian fermented beverage. Nature Sci. [Online]. 11(1). pp. 16-28. Available: http://www.sciencepub.net/nature.

[34] F. O. Oladeinde, E. I. Nwankwo, O. A. Moronkola, M. A. Amosu, and B. Farayola. (2002). Determination of indigenous and foreign alcoholic beverages' levels in urine by quantitative spectroscopy. Afri. J Biomed. Resear. [Online]. 5. pp. 73-76.

[35] I. S. Eneji, A. A. Asan, and A. U. Itodo. (April 2017). Physicochemical and microbial analysis of locally fermented drinks (burukutu and pito) from cereals in north central Nigeria. FUW Trends Sci. Tech. J. [Online]. 2(1B). pp. 433-438. Available: www.ftstjournal.com.

[36] R. J. de Souza, J. F. Swain, L. J. Appel, and F. M. Sacks. (2008). Alternatives for macronutrient intake and chronic disease: a comparison of the OmniHeart diets with popular diets and with dietary recommendations. Am. J Clin. Nutr. [Online]. 88(1). pp. 1-11. Available: https://academic.oup.com/ajcn/article/88/1/1/4648889.

[37] J. Slavin, and J. Carlson. (2014). Carbohydrates. Adv. Nutri. [Online]. 5. pp. 760-761. doi:10.3945/an.114.006163. Available: https://academic.oup.com/advances/article/5/6/760/4616690.

[38] J. Wylie-Rosett, K. Aebersold, B. Conlon, C. R. Isasi, and N. W. Ostrovsky. (April 2013). Health effects of low-carbohydrate diets: where should new research go? Curr. Diabetes Reports. [Online]. 13(2). pp. 271-278. doi:10.1007/s11892-012-0357-5.

[39] I. F. Fadahunsi, S. T. Ogunbanwo, and A. O. Fawole. (2013). Microbiological and nutritional assessment of burukutu and pito (indigenously fermented alcoholic beverages in West Africa) during storage. Nature Sci. [Online]. 11(4). pp. 98-103. Available: http://www.sciencepub.net/nature. 